\title{
Efficacy of land use designation in protecting habitat in the miombo woodlands: Insights from Tanzania
}

\author{
Alex L. Lobora \\ Tanzania Wildlife Research Institute (TAWIRI), Tanzania \\ P.O Box 661, Arusha \\ alex.lobora@tawiri.or.tz
}

Cuthbert L. Nahonyo

University of Dar es Salaam (UDSM), Tanzania

P.O Box 35064, Dar es salaam

nahonyo@udsm.ac.tz

\section{Linus K. Munishi}

Nelson Mandela African Institution of Science and Technology (NM-

AIST), Tanzania

P.O. Box 447, Arusha, TANZANIA

linus.munishi@nm-aist.ac.tz

\section{Tim Caro}

Department of Wildlife, Fish and Conservation Biology

University of California, Davis, USA

tmcaro@ucdavis.edu

\section{Charles Foley}

Wildlife Conservation Society, Tanzania Program

P.O Box 2703, Arusha

cfoley@wcs.org 


\section{Colin M. Beale}

Department of Biology

University of York, United Kingdom

Heslington, York

YO10 5DD

colin.beale@york.ac.uk

*Corresponding author:

Alex L. Lobora

Address: Tanzania Wildlife Research Institute, P.O Box 661, Arusha,

Tanzania

Mobile number: +255-784-301924; +255-754-301924

Fax: +255-27-2548240

alex.lobora@tawiri.or.tz

http://orcid.org/0000-0002-6067-4539

$\underline{\text { Word count }}$

Abstract: 193

Main text: 2820

Acknowledgements: 32

References: 94

Number of tables: 2

Number of figures: 3

Number of Appendices: 8 


\title{
Efficacy of land use designation in protecting habitat in the miombo woodlands: Insights from Tanzania
}

\begin{abstract}
Loss of natural landscapes surrounding major conservation areas compromise their future and threaten long-term conservation. We evaluate the effectiveness of fully and lesser protected areas within Katavi-Rukwa and Ruaha-Rungwa ecosystems in south-western Tanzania to protecting natural landscapes within their boundaries over the past four decades. Using a time series of Landsat satellite imageries of September 1972, July 1990 and September 2015, we assess the extent to which natural habitat has been lost within and around these areas mainly through anthropogenic activities. We also test the viability of the remaining natural habitat to provide connectivity between the two ecosystems. Our analysis reveals that while fully protected areas remained intact over the past four decades, lesser protected areas lost a combined total area of about $5,984 \mathrm{~km}^{2}$ during that period which is about $17.5 \%$ of habitat available in 1972 . We also find that about $3,380 \mathrm{~km}^{2}$ of natural habitat is still available for connectivity between the two ecosystems through Piti East and Rungwa South Open Areas. We recommend relevant authorities to establish conservation friendly village land use plans in all villages surrounding and between the two ecosystems to ensure long-term conservation of these ecosystems.
\end{abstract}

Keywords: landcover, landuse, habitat conversion, miombo, anthropogenic 


\section{Introduction}

About $15 \%$ of the land worldwide is currently designated as protected areas (henceforth "PAs") for biodiversity conservation (Juffe-Bignoli et al., 2014), and efforts are underway to further extend this to $17 \%$ of all terrestrial land and $10 \%$ of coastal and marine areas by 2020 (Di Minin \& Toivonen, 2015). These efforts indicate the importance that countries and the international communities attach to the role PAs play in preserving natural landscapes and reducing biodiversity loss over long-term (Dudley, 2008; Serra et al., 2008; Wyman \& Stein, 2010; Schulz et al., 2010; Gao and Liu, 2010; Gibbs et al., 2010; Lung \& Schaab, 2010; Leroux et al., 2010; Azadi \& Hasfiati, 2011; Estes et al., 2012; Bailey et al., 2016). However, poverty, population pressures and escalating demand for natural resources compounded by conflicting national policies, poor governance and weak institutions (Rao et al., 2009), have influenced the ability of PAs to fulfil their role (Brashares et al., 2001; Dwivedi et al., 2005; Shalaby \& Tateishi, 2007; Bakr et al., 2010). . While the expansion of PAs coverage and their contribution to nature conservation is well recognized (Pimm et al., 1995; Baillie et al., 1996; Myers et al., 2000; Bruner et al., 2001; Rodrigues et al., 2004a,b; Jenkins \& Joppa, 2009; Leverington et al., 2010; Machumu \& Yakupitiyage, 2013), there is increasing argument surrounding PAs' effectiveness in protecting biodiversity loss due to the wide spreading anthropogenic activities within and outside their boundaries (Pimm \& Raven, 2000; DeFries et al., 2005; Stoner et al., 2007a; Gardner et al., 2007; Bradshaw et al., 2009; Ahrends et al., 2010; Gibson et al., 2011; Laurance et al., 2011, 2012; Ghimire \& Pimbert, 2013; Clark et al., 2013; WWF, 2016).

Tanzania maintains a variety of PA categories which allow different levels of legal restrictions on resource use including fully protected areas (henceforth "FPAs") (constituting 17\% of land surface) comprising of national parks (only allow photographic tourism), game reserves (permit tourist hunting), forest reserves (some permit selective logging) and the Ngorongoro Conservation Area (NCA) which is similar to national parks but allows cattle grazing by indigenous Maasai pastoralists (MNRT, 2007; Stoner et al., 2007a). The rest of the PAs (constituting $18 \%$ of the country's land surface) are considered as lesser protected (henceforth "LPAs") and include Game Controlled Areas (GCAs) and Open 
Areas (OAs) where extractive resource use is permitted under license (MNRT, 2007). Wildlife Management Areas (WMAs) comprise Tanzania's newest protection category that aims to promote wildlife management at the village level by allowing rural communities and private land holders to manage wildlife on their land for their own benefit and devolving management responsibility of the settled areas and areas outside unsettled PAs to rural people and the private sector (USAID, 2013; WWF, 2014).

Despite having a variety of PA categories in place, there has been little effective evaluation of how well the different classes actually prevent habitat loss although efforts have been made on assessing wildlife numbers in these areas (Gardner et al., 2007; Stoner et al., 2007b). There is some evidence that overall habitat degradation is lower in Tanzania's PAs than outside (Pelkey et al., 2000; Beale et al 2013), but effective protection of forests within protected areas is certainly mixed (Pfeifer et al., 2012). While the IUCN guidelines advocate a rule of thumb law enforcement effort of one ranger/scout for every 10-50 sq.km (David et al., 2016), the mean effort available for FPAs and LPAs within the study area is one scout/ranger for every 143 and 346 sq.km respectively indicating minimal enforcement in both categories (Nahonyo, 2005). Here, we use time series satellite datasets to investigate the status of land-cover in the various landuse designations in the study area over the past four decades. More specifically, we assess the spatial extent of deforestation in both FPAs and LPAs during that period, establish which of the two PA categories is effective in halting habitat change during that period and quantify available potential habitat for connectivity between the two ecosystems. 


\subsection{Study area, materials and methods}

\subsection{Study area}

The study area covers about $109,050 \mathrm{~km}^{2}$ and lies between latitude $6^{0} 15 ' 59.38$ " to $8^{0} 10^{\prime} 23.78^{\prime \prime} \mathrm{S}$ and longitude $30^{\circ} 45^{\prime} 13.29^{\prime \prime}$ to $35^{\circ} 28$ '34.44" E. It comprises KataviRukwa ecosystem in the west, a contingent of Game Reserves (henceforth "GRs"), GCAs and OAs in the central part as well as Ruaha-Rungwa ecosystem in the East (Figure 1). About $45,961 \mathrm{~km}^{2}$ of this area is designated as FPAs (2 NPs, 7 GRs), 34,196 $\mathrm{km}^{2}$ designated as LPAs (8 GCAs and 8 OAs) herein also referred to in our analysis as Region Of Interest (ROI). A further $28,893 \mathrm{~km}^{2}$ of land within the study area was considered as unclassified land and hence excluded from the analysis and includes towns and highly populated hamlets north and south of Katavi National Park, east of Muhesi Game Reserve and south of Lunda - Nkwambi GCA (Figure 1).

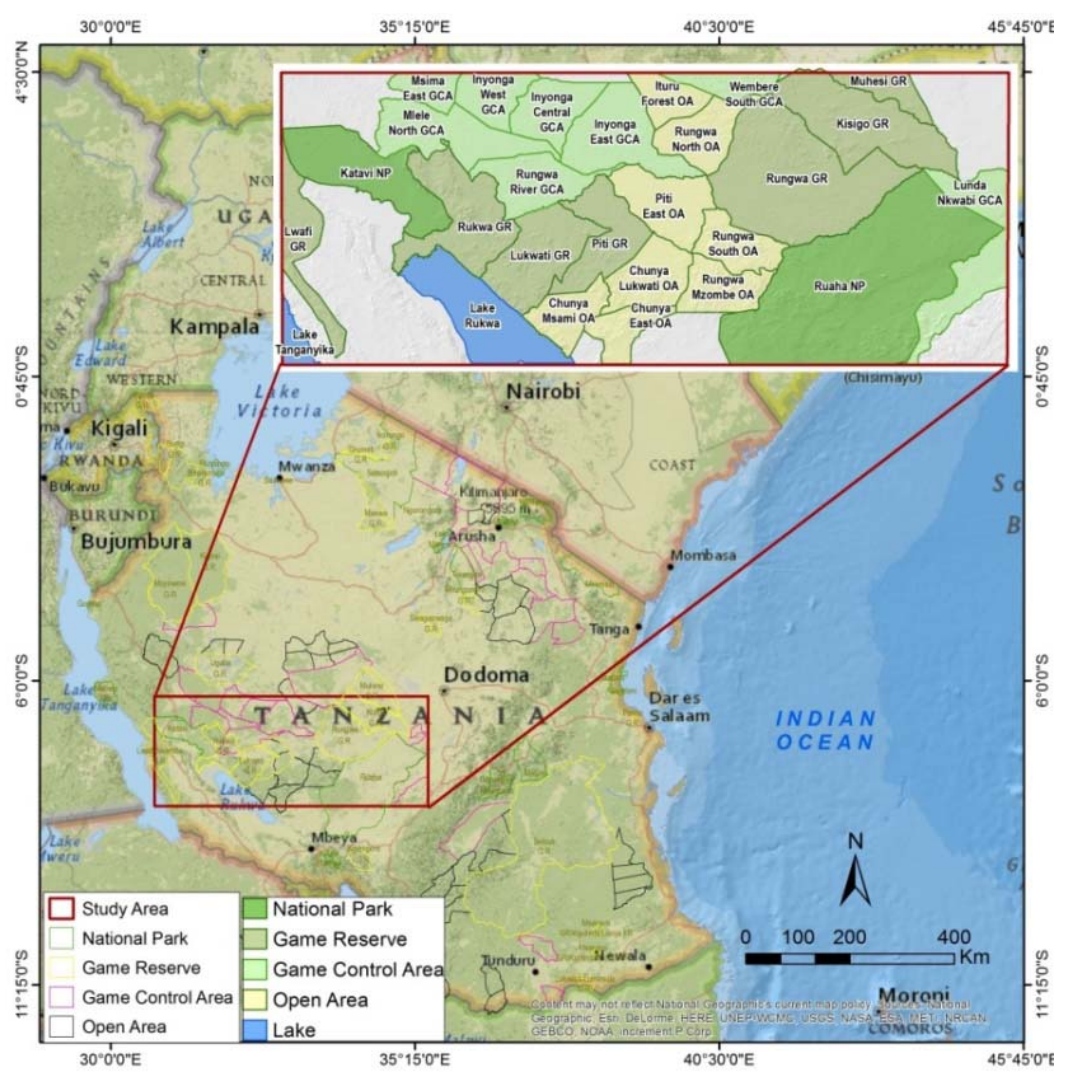

Figure 1: Study Area

[Insert figure 1 about here] 


\subsection{Methods}

\subsubsection{Data collection}

Our analysis employed Landsat Multispectral Scanner (MSS), Landsat Thematic Mapper (TM) and Landsat Enhanced Thematic Mapper $\left(\mathrm{ETM}^{+}\right)$for 1972, 1990 and 2015 respectively. The study area contained an intersection of 12 Landsat footprints (path/row 168/064, 169/064, 170/064, 171/064, 171/065, 170/065, 169/065, 168/065, 171/066, 170/066, 169/066 (Annexes 1-3). Cloud free Landsat images were downloaded from USGS website in single band GEOTIFF format pre-processed for atmospheric correction, geometric correction and noiseremoval. The TM sensor has seven spectral bands (Boettinger et al., 2008; Brink \& Eva, 2009) and is primarily designed to detect reflected radiation from the Earth's surface in the visible and near-infrared (IR) wavelengths (Shalaby \& Tateishi 2007).

We obtained land-use data from the Tanzania Wildlife Research Institute (TAWIRI), a local government organ responsible for providing scientific information for promoting the development, improvement and protection of the wildlife industry. The dataset included boundaries of NPs, GRs, GCAs, and OAs and road networks.

\subsubsection{Image pre-processing}

We used a combination of ENVI version 5.1 (Exelis Visual Information Solutions, Boulder, Colorado, USA) and ArcMap module of the ArcGIS 10x software for image preparation and processing. The first step involved georeferencing images using known locations taken across the study area to reduce registration error (Jensen, 1996). We then applied image enhancement tool in ArcMap to improve visual interpretability by increasing the apparent distinction between different image features (Bradley \& Mustard, 2005; Shalaby \& Tateishi 2007). We further normalised each band stretching from 0 to 255 to improve visibility of different bodies with similar tones. To improve interpretability, we colour composited individual image bands to generate Colour Composites. For 
analysis we used bands 2, 3, and 4 for Landsat TM and ETM+ images and bands 6, 5 and 4 for Landsat MSS images.

\subsubsection{Image processing}

Image interpretation involved a combination of supervised and unsupervised (hybrid) classification (Brink \& Eva, 2009). We first performed unsupervised classification using an Iterative Self-Organizing Data Analysis Technique Algorithm (ISODATA) which has been shown to perform better because of the statistical power it employs when classifying an unknown pixel (Shalaby \& Tateishi, 2007; Brink and Eva, 2009). We set our preliminary classification result to yield a maximum of 30 spectral classes for historical $(1972,1990)$ and current (2015) maps (Ball \& Hall, 1965). To obtain hybrid land cover maps, we visually interpreted and assigned the relevant landcover classes (from unsupervised classification) with the help of field data, Google earth images, expert knowledge and the recent countrywide landcover map developed by the National Forest Resources Monitoring and Assessment (NAFORMA) project (NAFORMA, 2015). Landcover classes for the final maps included Closed woodland, Open woodland, Bushland, Settlement/Cultivation, Wetland and Water. Description of theses land cover classes are provided in Table 1. 
Table 1: Description of different land covers classes of the study area

\begin{tabular}{|c|c|}
\hline Land cover & Description \\
\hline Closed woodland & Tree layer with crown cover $>40 \%$ \\
\hline Open woodland & Tree layer with crown cover $\geq 10 \%$ and $\leq 40 \%$ \\
\hline Bushland & $\begin{array}{l}\text { Mixed vegetation types including thicket, dense bushland, } \\
\text { bushland with scattered cultivation and Open bushland }\end{array}$ \\
\hline Settlement/Cultivation & $\begin{array}{l}\text { Open and cultivated agricultural grasslands mixed with } \\
\text { settlement,grassland, shrubland, and impervious surfaces }\end{array}$ \\
\hline Wetland & $\begin{array}{l}\text { Vegetated lands with a high water table and inundated } \\
\text { vegetation }\end{array}$ \\
\hline Bare/Open Areas & $\begin{array}{l}\text { Land areas of exposed soil surface as influenced by human } \\
\text { impacts and/or natural causes. It contains sparse vegetation } \\
\text { with very low plant cover value as a result of overgrazing, } \\
\text { woodcutting, etc. }\end{array}$ \\
\hline Water & $\begin{array}{l}\text { Areas covered with water most of the year, Lakes, ocean, } \\
\text { river, etc. }\end{array}$ \\
\hline
\end{tabular}

Source: National Forestry Resources Monitoring and Assessment of Tanzania

Field Manual (NAFORMA, 2010).

[Insert table 1 about here] 


\subsubsection{Accuracy assessment}

We assessed accuracy (Landgrebe, 2003; Mather, 2004) using 254 random points chosen to represent different land cover classes across the study area collected in 2015. We determined both omission error/producer accuracy to measure how well our images have been classified, commission error/user's accuracy to determine reliability of a pixel class on the map and the category on the ground as well as Kappa (Hat) to measures of agreement between the classification and the reference data (Olofsson et al., 2014). Accuracy above $85 \%$ is considered within the acceptable range (Anderson et al., 1976; Lins \& Kleckner, 1996) while Kappa statistic above $80 \%$ is considered strong (Jensen, 1996). To obtain overall accuracy, we divided the total number of correct pixels (diagonal) by the total number of pixels in the error matrix (Olofsson et al., 2014). We could not assess accuracies for historical land-cover maps due to the lack of historical reference points.

\subsubsection{Detecting change}

Change detection (Singh 1989; Coppin, 2004) involved identifying pixels that were previously natural habitat in 1972 but later changed to field crops and settlements in 2015. To do this we carried out a pixel based raster analysis in $R(R$ Core team, 2016) in three phases namely between 1972 and 1990, 1990 and 2015 as well as the overall change between 1972 and 2015 (Appendix H). The analysis generated three different change tables as per the above phases and subsequently merged and used to calculate respective changes.

\section{Results}

\subsection{Land-cover classification and accuracy assessment}

Overall accuracy assessment and Kappa coefficients for the 2015 final land-cover map (Figure 2) are $89 \%$ and $87 \%$ respectively (Table 2). User's and producer's accuracies for individual land-cover classes are high suggesting correct assignment of individual classes during classification (Table 2). 
Table 2: Classification error matrix based on ground truth data collected in the study area Reference data

Classification data Closed Woodland Open Woodland Bushland Crop fields Wetland Water User accuracy

\begin{tabular}{lrrrrrrr}
\hline Closed woodland & 39 & 1 & 0 & 0 & 0 & 0 & $\mathbf{9 8}$ \\
Open woodland & 11 & 49 & 6 & 2 & 2 & 0 & $\mathbf{7 0}$ \\
Bushland & 0 & 0 & 43 & 2 & 2 & 0 & $\mathbf{9 1}$ \\
Crop fields & 0 & 0 & 0 & 46 & 0 & 0 & $\mathbf{1 0 0}$ \\
Wetland & 0 & 0 & 1 & 0 & 15 & 0 & $\mathbf{9 4}$ \\
Water & 0 & 0 & 0 & 0 & 0 & 35 & $\mathbf{1 0 0}$ \\
Producer Accuracy & $\mathbf{7 8}$ & $\mathbf{9 8}$ & $\mathbf{8 6}$ & $\mathbf{9 2}$ & $\mathbf{7 9}$ & $\mathbf{1 0 0}$ & \\
Overall Accuracy & 89 & & & & & & \\
Kappa statistics & 87 & & & & & &
\end{tabular}

Note: Percentage of pixels classified is shown by class with kappa statistic and producer, user and overall accuracy. 


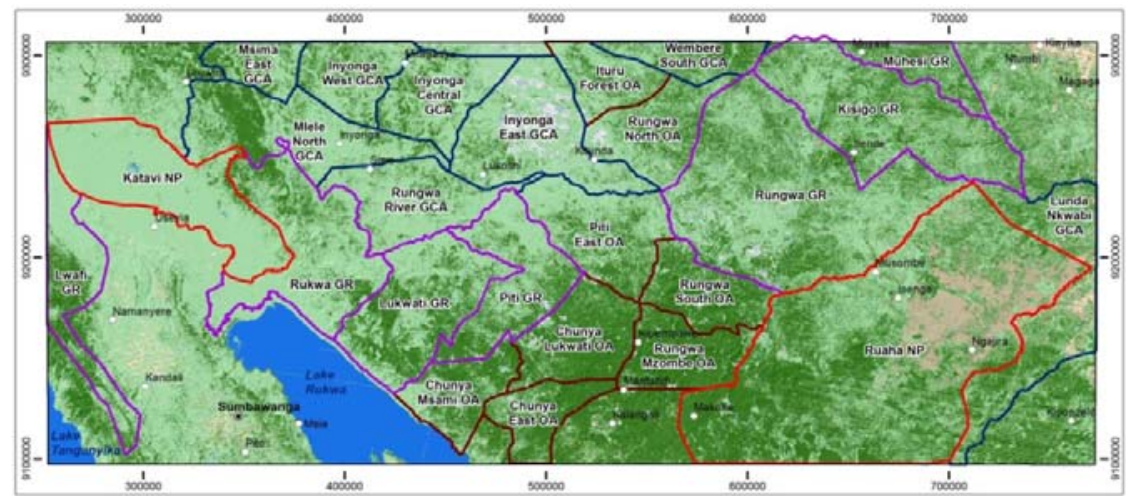

2(a)

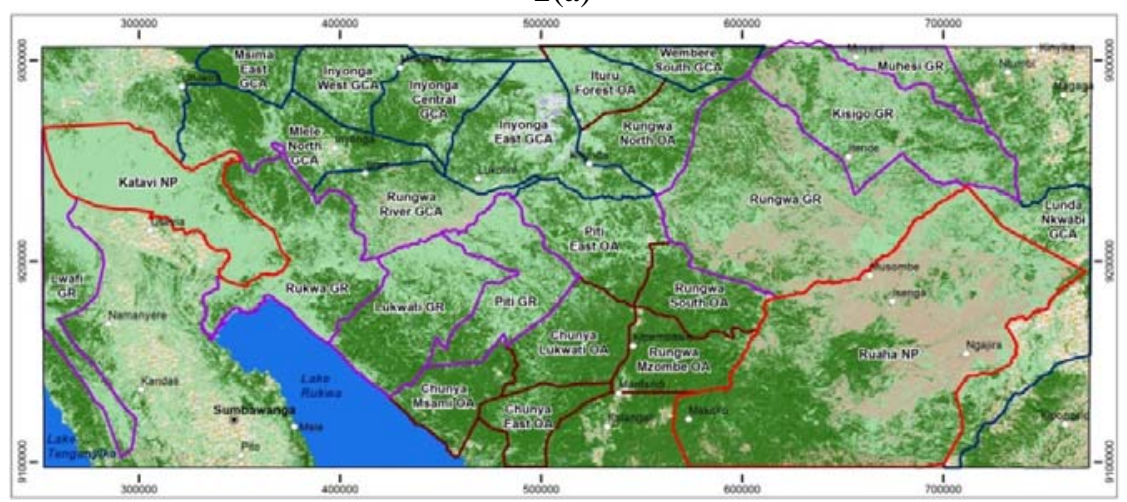

2(b)
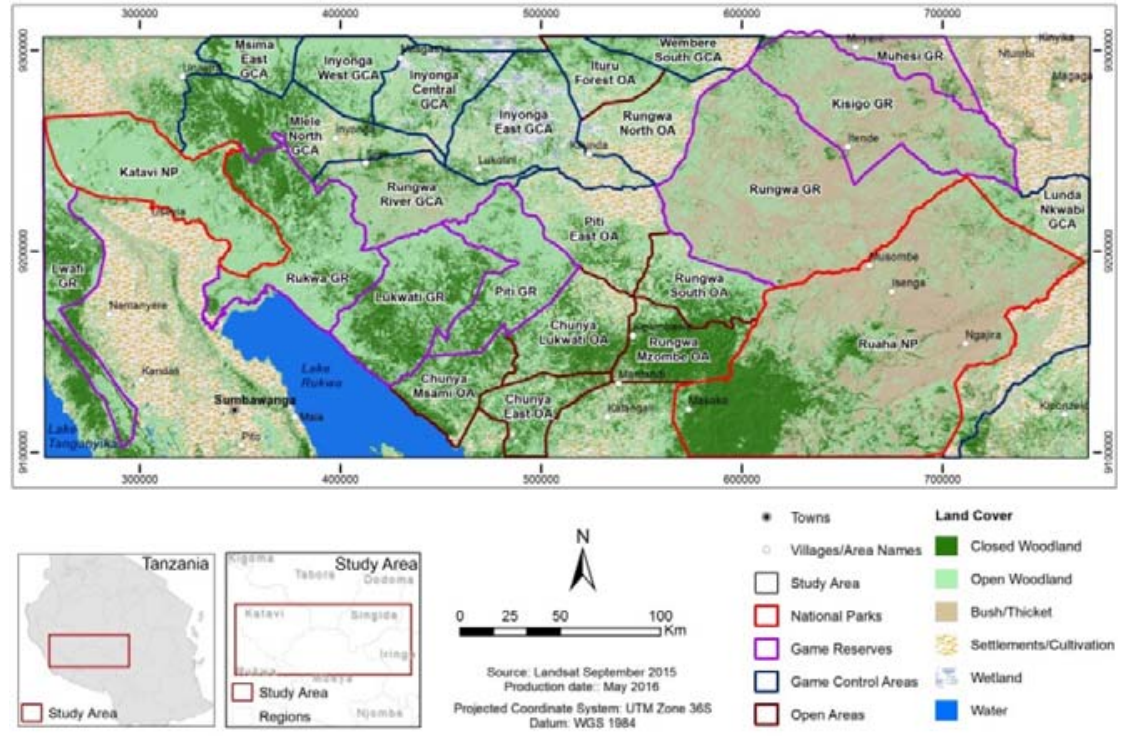

2(c)

Figure 2: Landcover maps for the study area showing trends in habitat decline over years. 2 (a) Landcover map of the study area in 1972 indicating that closed and open woodlands combined comprised a large proportion of the study area then. 2(b) Landcover map for the study area in 1990 indicating dominance of closed and open woodlands combined still comprised a large proportion of the study area. 2(c) Landcover map of the study area in 2015 indicating massive reduction in natural habitat. National Parks (Katavi and Ruaha) and Game Reserves (Rukwa, Lukwati, Piti, Rungwa, Kisigo and Muhesi) landscapes remained intact whilst Game Controlled Areas (GCAs and OAs) are significantly reduced to crop fields and settlements at the expense of natural habitat.

[Insert Figure 2 about here] 


\subsection{Status of landuse/cover in and around LPAs (GCAs and OAs)}

In 1972, areas between and surrounding the two ecosystems entirely comprised of natural habitat (Figure 2a). Two decades later (between $1972 \&$ 1990), these areas combined lost an estimated $1,060 \mathrm{~km}^{2}$ of natural habitat to crop fields and settlements equivalent to $3 \%$ of natural habitat available in 1972 (Figure 2b, Appendix F). Much of the loss occurred between 1990 and 2015 where an estimated $4,900 \mathrm{~km}^{2}$ of natural habitat was lost to crop fields and settlements which is equivalent to 6\% of habitat available in 1972 (Figure 3). Piti East and Rungwa South Open Areas which provide the potential habitat for connectivity between the two ecosystems lost a combined total area of about $1,200 \mathrm{~km}^{2}$ of natural habitat to crop field and settlement between 1972 and 2015, with $89 \%$ of the loss occurring between 1990 and 2015 (Figure 2c). Overall, habitat within and around LPAs have lost an estimated $5,984 \mathrm{~km}^{2}$ (equivalent to $17.5 \%$ ) of natural habitat to agricultural and settlement activities between 1972 and 2015 (Figure 3, Appendix F).

\subsection{Status of landuse/cover in FPAs (NPs and GRs)}

Apart from subtle habitat losses detected in Muhesi and Rukwa Game Reserves, FPAs remained relatively intact throughout suggesting their land use designation has been effective in preventing habitat loss over long term (Figure 3, Appendix E). 


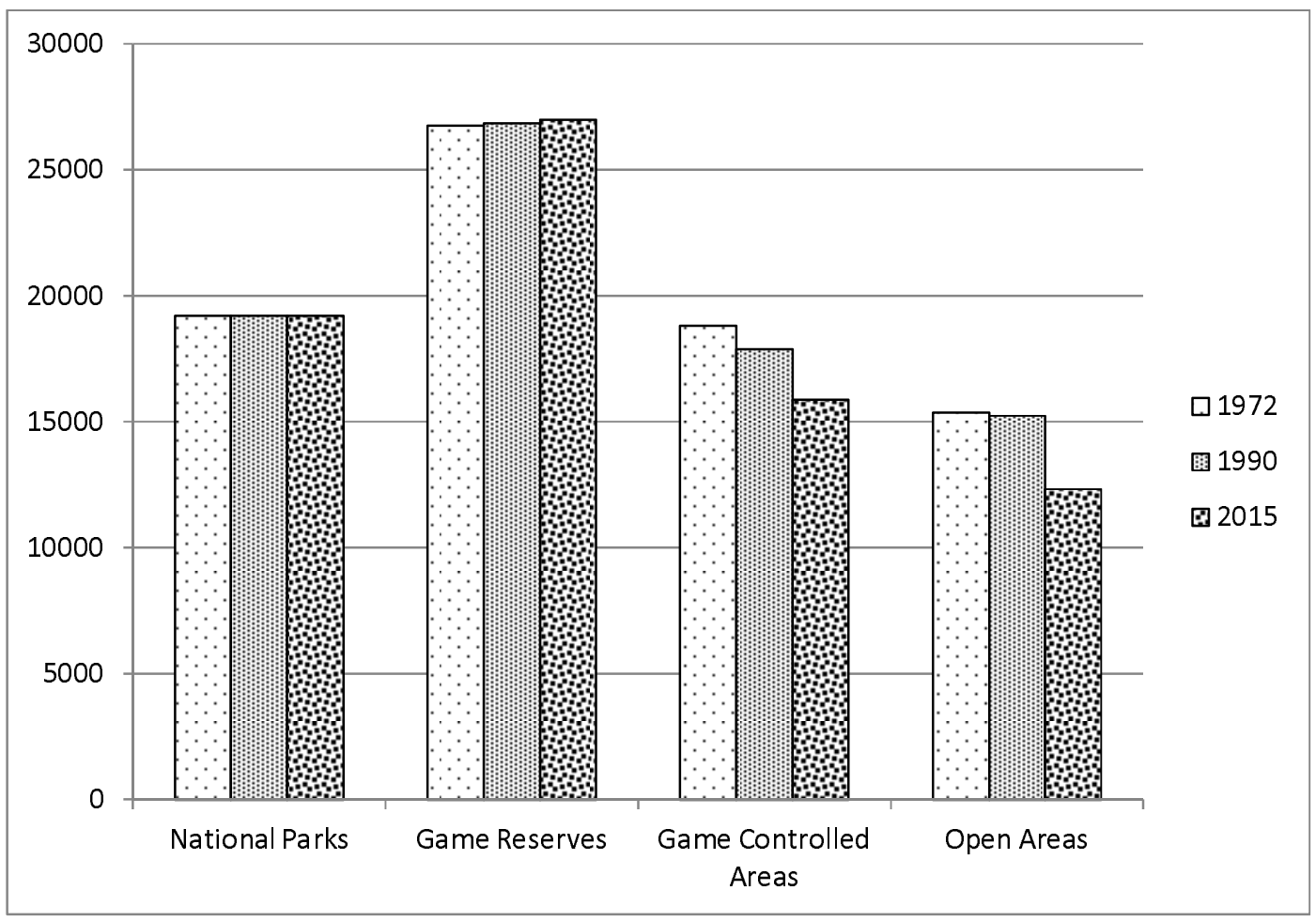

Figure 3: Overall habitat reduction (in $\mathrm{km}^{2}$ ) in all four land use categories in the study area between 1972 and 2015. Habitat in National Parks and Game Reserves remain unchanged throughout suggesting the effectiveness of full protection.

[Insert Figure 3 about here] 


\section{Discussion}

Our analysis revealed that FPAs are effective at preventing total habitat loss in the study area, despite minimal investment in enforcement (Figure 3, Appendix E). Our results support previous findings conducted across the country which found an increase in vegetative cover in FPAs with LPAs suffering worse habitat degradation than areas with no legal protection (Pelkey et al., 2000). In addition, a study conducted across tropical countries that found $83 \%$ of PAs were effective at preventing land clearance (Bruner et al., 2001). While habitat within FPAs in the study area remained relatively intact with minimum investment, we note that this may overlook losses of high valuable tree species such as African Blackwood Dalbergia melanoxylon and sealing-wax tree Pterocarpus angolensis (Caro et al., 2005) that may be selectively removed from within the miombo woodlands without total habitat loss (Appendix G). Our on the ground experience affirms this is happening in this part of Tanzania on large scale (Caro et al., 2005). Extensive selective cutting of high valued tree species is not only widespread in all PA categories within the study area but also documented elsewhere within FPAs in central Tanzania where increasing rarity has compelled wood carvers to shift to less preferred Miombo species Brachystegia speciformis (Madulu, 2001). Similarly, there is evidence of widespread elephant poaching within FPAs across the sub Saharan Africa (Brennan \& Kalsi, 2015), and in the Ruaha ecosystem in particular (TAWIRI, 2014; Chase et al., 2016), suggesting again a distinction between successful habitat preservation and successful protection of high value species within that habitat.

In contrast to FPAs, LPAs in the ROI have experienced rapid habitat loss in the study area, with $17.5 \%$ transformed to agricultural activities between 1972 and 2015. Most LPAs within the study area and elsewhere in the country have limited resources for enforcement. LPAs such as Piti East and Rungwa South OAs rely for help from adjacent FPAs namely Piti and Rungwa Game Reserves respectively (pers. obs.). Much of the conversion in these areas can be attributed to weak enforcement coupled with increased human population densities attracted by nearby resources (Wittemyer et al., 2008; c.f. Serengeti NP: Metzger et al., 2010) and the poor ability of the land to sustain agriculture (Campbell,1996; Malmer, 
2007). In many cases, human conversion of natural habitats occur most rapidly in the locations important to biodiversity because humans and biodiversity tend to be concentrated in the same locations (Hansen et al., 2012), often resulting in elevated levels of exploitation in these locations (Brashares et al., 2001; Parks \& Harcourt, 2002).

Miombo woodland generally occurs on low fertility soils which limits intensive agriculture, causing people to adopt destructive and unstable forms of agriculture and pastoralism activities (MacKinnon et al., 1986; Malmer, 2007), often at the expense of natural habitat (Mwalyosi, 1991). This leads to shifting agriculture not only because fertility declines fast on newly-cleared fields, but also because invasion of weeds makes it labour intensive to re-cultivate and hence they are often abandoned (MacKinnon et al., 1986). Such losses outside FPAs are a concern, because wide ranging species such as African elephants require vast areas that may not be provided by FPAs to guarantee long-term survival (McNeely \& Scherr, 2003; Zuidema \& Sayer 2003; Laurance et al. 2006; Michalski et al. 2007; Vandermeer \& Perfecto 2007; Harvey et al. 2008; Hansen et al.,2012). For example, African elephants spend a substantial amount of their time outside protected areas in Northern Tanzania (e.g. Tarangire National Park: Galanti et al., 2006) and elsewhere (Douglas-Hamilton et al., 2005). Escalating habitat loss through expanding agricultural and pastoralist activities within LPAs and around FPAs across the country threatens the few remaining corridors (Caro et al., 2009; Jones et al., 2009) and could potentially reduce genetic exchange (Rodrigues et al., 2004a; Newmark, 2008; Graham et al., 2009; Craigie et al., 2010).

Currently, Tanzania has about $17 \%$ of her land area devoted to wildlife conservation in PAs where no human settlement is allowed and further $18 \%$ of its surface area to PAs where wildlife co-exist with humans (MNRT, 2007). This network of PAs is coming under intense public scrutiny, with the government seeking to ensure development and conservation are adequately balanced across the country (Rutasitara et al., 2010) and there is little desire to increase the proportion of land in FPAs (Kideghesho et al., 2007). Indeed, the recent Southern Agricultural Growth Corridor of Tanzania (SAGCOT) initiative 2011 is explicitly 
targeting intensification of agriculture within the coastal plains and the valleys of Kilombero and Ruaha, on the hills and valleys of the Southern Highlands and the Usangu flats, including many areas of high biodiversity value (Milder et al., 2013; Wuyts \& Kilama, 2015).

Out of an estimated $26,090 \mathrm{~km}^{2}$ of natural habitat that remains in ROI today, about $3,380 \mathrm{~km}^{2}$ within Piti East and Rungwa provides potential habitat for connectivity between Rukwa-Katavi and Ruaha-Rungwa ecosystems (Appendix D). Both Piti East and Rungwa permit utilization through hunting of big game animals. However, Piti East OA was recently abandoned by hunting companies due to increasing number of cattle in the vicinity coupled with a substantial decline in large mammal populations, rendering the block currently uneconomical. The lack of interested hunting companies to invest in Piti East OA makes it vulnerable to greater habitat loss. Adequately protecting these two areas could secure connectivity between the two largest populations of African elephants of KataviRukwa and Ruaha-Rungwa ecosystems in south-western Tanzania (Jones et al., 2009). 


\section{Recommendations}

Protecting the remaining habitat connecting Ruaha-Rungwa \& Katavi-Rukwa ecosystems is a high priority. Increasing enforcement in LPAs within the study area and the country at large could help reduce the on-going conversions given the current political situation encouraging WMA establishment than new FPAs, although in practice it achieves the same result if well implemented. Additionally, the land here is marginal at best for agriculture, so the development of a WMA offers solution that could allow greater local community buy-in. The area will need restoration before it can be economically self-sustaining and this needs investment, with some initial funds expected from Wildlife Conservation Society (WCS), Reducing Emissions from Deforestation and Degradation (REDD) programs offers others funding sources. Our analysis suggests that without increased protection this corridor will be lost in the next few years.

\section{Acknowledgments}

We would like to thank Ms Rose Mayienda for assisting with data processing, Wildlife Conservation Society (WCS) Tanzania country office and the Tanzania Wildlife Research Institute (TAWIRI) for financially supporting this study.

\section{Funding}

This research did not receive any specific grant from funding agencies in the public, commercial, or not-for-profit sectors. 


\section{References}

Ahrends, A., Burgess, N. D., Milledge, S. A., Bulling, M. T., Fisher, B., Smart, J. C., ... \& Lewis, S. L. (2010). Predictable waves of sequential forest degradation and biodiversity loss spreading from an African city. Proceedings of the National Academy of Sciences, 107(33), 14556-14561.

Anderson, J. R., Hardy, E. E., Roach, J. T., \& Witmer, R. E. (1976). US Geological Survey Professional Paper 964. Washington, DC: US Government Printing Office.

Azadi, H., Ho, P., \& Hasfiati, L. (2011). Agricultural land conversion drivers: A comparison between less developed, developing and developed countries. Land Degradation \& Development, 22(6), 596-604.

Bailey, K. M., McCleery, R. A., Binford, M. W., \& Zweig, C. (2016). Land-cover change within and around protected areas in a biodiversity hotspot. Journal of Land Use Science, 11(2), 154-176.

Baillie, J., Groombridge, B., Gärdenfors, U. L. F., \& Stattersfield, A. J. (1996). IUCN Red List of threatened animals. Iucn.

Bakr, N., Weindorf, D. C., Bahnassy, M. H., Marei, S. M., \& El-Badawi, M. M. (2010). Monitoring land cover changes in a newly reclaimed area of Egypt using multitemporal Landsat data. Applied Geography, 30(4), 592-605.

Ball, G. H., \& Hall, D. J. (1965). ISODATA, a novel method of data analysis and pattern classification. STANFORD RESEARCH INST MENLO PARK CA.

Beale, C. M., Baker, N. E., Brewer, M. J., \& Lennon, J. J. (2013). Protected area networks and savannah bird biodiversity in the face of climate change and land degradation. Ecology letters, 16(8), 1061-1068.

Boettinger, J. L., Ramsey, R. D., Bodily, J. M., Cole, N. J., Kienast-Brown, S., Nield, S. J., ... \& Stum, A. K. (2008). Landsat spectral data for digital soil mapping. In Digital Soil Mapping with limited data (pp. 193-202). Springer Netherlands.

Bradley, B. A. and Mustard, J. F. (2005). Identifying land cover variability distinct from land cover change: Cheatgrass in the Great Basin: Remote Sensing of Environment $94204-213$. 
Bradshaw, C. J., Sodhi, N. S., \& Brook, B. W. (2009). Tropical turmoil: a biodiversity tragedy in progress. Frontiers in Ecology and the Environment, 7(2), 79-87.

Brashares, J. S., Arcese, P., \& Sam, M. K. (2001). Human demography and reserve size predict wildlife extinction in West Africa. Proceedings of the Royal Society of London B: Biological Sciences, 268(1484), 2473-2478.

Brennan, A. J., \& Kalsi, J. K. (2015). Elephant poaching \& ivory trafficking problems in Sub-Saharan Africa: An application of O'Hara's principles of political economy. Ecological Economics, 120, 312-337.

Brink, A. B., \& Eva, H. D. (2009). Monitoring 25 years of land cover change dynamics in Africa: A sample based remote sensing approach. Applied Geography, 29(4), 501-512.

Bruner, A. G., Gullison, R. E., Rice, R. E., \& Da Fonseca, G. A. (2001). Effectiveness of parks in protecting tropical biodiversity. Science, 291(5501), 125-128.

Campbell, B. M. (Ed.). (1996). The Miombo in transition: woodlands and welfare in Africa. Cifor.

Caro, T. M., Sungula, M., Schwartz, M. W., \& Bella, E. M. (2005). Recruitment of Pterocarpus angolensis in the wild. Forest Ecology and Management, 219(2), 169-175.

Caro, T., Jones, T., \& Davenport, T. R. (2009). Realities of documenting wildlife corridors in tropical countries. Biologicalconservation, 142(11), 2807-2811.

Caro, T.M (1999). Densities of mammals in lesser protected areas: the Katavi ecosystem of western Tanzania. Journal of Applied Ecology, 36, 205-217.

Chase, M. J., Schlossberg, S., Griffin, C. R., Bouché, P. J., Djene, S. W., Elkan, P. W., ... \& Omondi, P. (2016). Continent-wide survey reveals massive decline in African savannah elephants. PeerJ, 4, e2354.

Clark, N. E., Boakes, E. H., McGowan, P. J., Mace, G. M., \& Fuller, R. A. (2013). Protected areas in South Asia have not prevented habitat loss: a study using historical models of land-use change. PloS one, 8(5), e65298.

Coppin, P., Jonckheere, I., Nackaerts, K., Muys, B., \& Lambin, E. (2004). Digital change detection methods in ecosystem monitoring: a review. International Journal of Remote Sensing, 25, 1565-1596. 
Craigie, I. D., Baillie, J. E., Balmford, A., Carbone, C., Collen, B., Green, R. E., \& Hutton, J. M. (2010). Large mammal population declines in Africa's protected areas. Biological Conservation, 143(9), 2221-2228.

David W. Henson, Robert C. Malpas and Floris A.C. D’Udine (2016). Wildlife Law Enforcement in Sub-Saharan African Protected Areas - A Review of Best Practices. Occasional Paper of the IUCN Species Survival Commission No. 58. Cambridge,UK and Gland, Switzerland: IUCN. xxii+65pp.

DeFries, R., Hansen, A., Newton, A. C., \& Hansen, M. C. (2005). Increasing isolation of protected areas in tropical forests over the past twenty years. Ecological Applications, 15(1), 19-26.

Di Minin, E., \& Toivonen, T. (2015). Global protected area expansion: creating more than paper parks. BioScience, 65(7), 637-638.

Douglas-Hamilton, I., Krink, T., \& Vollrath, F. (2005). Movements and corridors of African elephants in relation to protected areas. Naturwissenschaften, 92(4), 158-163.

Dudley, N. (2008). Guidelines for applying protected area management categories. IUCN.

Dwivedi, R. S., Sreenivas, K., \& Ramana, K. V. (2005). Cover: Land $\square$ use/land $\square$ cover change analysis in part of Ethiopia using Landsat Thematic Mapper data. International Journal of Remote Sensing, 26(7), 12851287.

Estes, A. B., Kuemmerle, T., Kushnir, H., Radeloff, V. C., \& Shugart, H. H. (2012). Land-cover change and human population trends in the greater Serengeti ecosystem from 1984-2003. Biological Conservation, 147(1), 255263.

Galanti, V., Preatoni, D., Martinoli, A., Wauters, L. A., \& Tosi, G. (2006). Space and habitat use of the African elephant in the Tarangire-Manyara ecosystem, Tanzania: Implications for conservation. Mammalian Biology-Zeitschrift für Säugetierkunde, 71(2), 99-114.

Gao, J., \& Liu, Y. (2010). Determination of land degradation causes in Tongyu County, Northeast China via land cover change detection. International Journal of Applied Earth Observation and Geoinformation, 12(1), 9-16. 
Gardner, T. A., Caro, T. I. M., Fitzherbert, E. B., Banda, T., \& Lalbhai, P. (2007). Conservation value of multiple $\square$ use areas in East Africa. Conservation Biology, 21(6), 1516-1525.

Ghimire, K. B., \& Pimbert, M. P. (2013). Social change and conservation(Vol. 16). Routledge.

Gibbs, H. K., Ruesch, A. S., Achard, F., Clayton, M. K., Holmgren, P., Ramankutty, N., \& Foley, J. A. (2010). Tropical forests were the primary sources of new agricultural land in the 1980s and 1990s. Proceedings of the National Academy of Sciences, 107(38), 16732-16737.

Gibson, L., Lee, T. M., Koh, L. P., Brook, B. W., Gardner, T. A., Barlow, J., ... \& Sodhi, N. S. (2011). Primary forests are irreplaceable for sustaining tropical biodiversity. Nature, 478(7369), 378-381.

Graham, M. D., Douglas-Hamilton, I., Adams, W. M. \& Lee, P. C. 2009 The movement of African elephants in a human-dominated land-use mosaic. Anim. Conserv. 12, 445-455. (doi:10.1111/j.1469-1795.2009.00272.x)

Hansen, A. J., DeFries, R. S., \& Turner, W. (2012). Land use change and biodiversity. In Land Change Science (pp. 277-299). Springer Netherlands.

Harvey, C. A., Komar, O., Chazdon, R., Ferguson, B. G., Finegan, B., Griffith, D. M., ... \& Van Breugel, M. (2008). Integrating agricultural landscapes with biodiversity conservation in the Mesoamerican hotspot.Conservation biology, 22(1), 8-15.

Jenkins, C. N., \& Joppa, L. (2009). Expansion of the global terrestrial protected area system. Biological Conservation, 142(10), 2166-2174.

Jensen, J. R. (1996). Introductory digital image processing. A remote sensing perspective (2nd ed.). New Jersey: Prentice-Hall.

Jones, T., Caro, T. \& Davenport, T.R.B (2009) Wildlife Corridors in Tanzania. Unpublished report. Tanzania Wildlife Research Institute (TAWIRI), Arusha. $60 \mathrm{pp}$.

Juffe-Bignoli, D., Burgess, N.D., Bingham, H., Belle, E.M.S., de Lima, M.G., Deguignet, M., Bertzky, B.,Milam, A.N., Martinez-Lopez, J., Lewis, E., Eassom, A., Wicander, S., Geldmann, J., van Soesbergen, A.,Arnell, A.P., O’Connor, B., Park, S., Shi, Y.N., Danks, F.S., MacSharry, B., Kingston, N. (2014). Protected Planet Report 2014. UNEP-WCMC: Cambridge, UK. 
Kideghesho, J. R., Røskaft, E., \& Kaltenborn, B. P. (2007). Factors influencing conservation attitudes of local people in Western Serengeti,

Tanzania. Biodiversity and Conservation, 16(7), 2213-2230.

Landgrebe, D.A 2003 Signal Theory Methods in Multispectral Remote Sensing. Hoboken, NJ: John Wiley and Sons.

Laurance, W. F., Camargo, J. L., Luizão, R. C., Laurance, S. G., Pimm, S. L., Bruna, E. M., ... \& Van Houtan, K. S. (2011). The fate of Amazonian forest fragments: a 32-year investigation. Biological Conservation, 144(1), 56-67.

Laurance, W. F., Croes, B. M., Tchignoumba, L., Lahm, S. A., Alonso, A., Lee, M. E., ... \& Ondzeano, C. (2006). Impacts of roads and hunting on central African rainforest mammals. Conservation Biology, 20(4), 1251-1261.

Laurance, W. F., Useche, D. C., Rendeiro, J., Kalka, M., Bradshaw, C. J., Sloan, S. P., ... \& Arroyo-Rodriguez, V. (2012). Averting biodiversity collapse in tropical forest protected areas. Nature, 489(7415), 290-294.

Leroux, S. J., Krawchuk, M. A., Schmiegelow, F., Cumming, S. G., Lisgo, K., Anderson, L. G., \& Petkova, M. (2010). Global protected areas and IUCN designations: Do the categories match the conditions?. Biological conservation, 143(3), 609-616.

Leverington, F., Costa, K. L., Pavese, H., Lisle, A., \& Hockings, M. (2010). A global analysis of protected area management effectiveness. Environmental Management, 46(5), 685-698.

Lewis, D., Kaweche, G. B., \& Mwenya, A. (1990). Wildlife conservation outside protected areas-lessons from an experiment in Zambia. Conservation Biology, 4(2), 171-180.

Lins, K. S., \& Kleckner, R. L. (1996). Land cover mapping: An overview and history of the concepts. Gap analysis: A landscape approach to biodiversity planning, 57-65.

Lung, T., \& Schaab, G. (2010). A comparative assessment of land cover dynamics of three protected forest areas in tropical eastern Africa.Environmental monitoring and assessment, 161(1-4), 531-548.

Machumu, M. E., \& Yakupitiyage, A. (2013). Effectiveness of Marine Protected Areas in Managing the Drivers of Ecosystem Change: A Case of Mnazi Bay Marine Park, Tanzania. Ambio, 42(3), 369-380. 
MacKinnon, J., MacKinnon, K., Child, G., \& Thorsell, J. W. (1986). Managing protected areas in the tropics. Based on workshops, World congress on national parks, Bali, Indonesia, October 1982, organized by the IUCN Commission on National Parks and Protected Areas. In Managing protected areas in the tropics. Based on workshops, World congress on national parks, Bali, Indonesia, October 1982, organized by the IUCN Commission on National Parks and Protected Areas. International Union for Conservation of Nature and Natural Resources

Madulu, N. F. (2001). Population dynamics and sustainable conservation of protected areas in Tanzania. The case of Swagaswaga Game Reserve in Kondoa District, Report in Environmental Assessment (READ), Applied Environmental Impact Assessment, Uppsala University, Sweden, 26.

Malmer, A. (2007). General ecological features of miombo woodlands and considerations for utilization and management. In MITMIOMBOManagement of Indigenous Tree Species for Ecosystem Restoration and Wood Production in Semi-Arid Miombo Woodlands in Eastern Africa. Proceedings of the First MITMIOMBO Project Workshop held in Morogoro, Tanzania (pp. 6-12).

Mather, P.M 2004 Computer Processing of Remotely-Sensed Images: An introduction, 3rd edn (Chichester: John Wiley \& Sons).

McNeely, J. A., \& Scherr, S. J. (2003). Ecoagriculture: strategies to feed the world and save wild biodiversity. Island Press.

Metzger, K. L., Sinclair, A. R. E., Hilborn, R., Hopcraft, J. G. C., \& Mduma, S. A. (2010). Evaluating the protection of wildlife in parks: the case of African buffalo in Serengeti. Biodiversity and Conservation, 19(12), 3431-3444.

Michalski, F., \& Peres, C. A. (2007). Disturbance $\square$ mediated mammal persistence and abundance $\square$ area relationships in Amazonian forest fragments. Conservation Biology, 21(6), 1626-1640.

Milder, J. C., Buck, L. E., Hart, A. K., Scherr, S. J., \& Shames, S. A. (2013). A framework for Agriculture Green Growth: Greenprint for the Southern Agricultural Growth Corridor of Tanzania (SAGCOT). Dar es Salaam: SAGCOT Centre.

MNRT (2007) The Wildlife Policy of Tanzania. Revised in March 2007 
Mwalyosi, R. B. B. 1991. Ecological evaluation for wildlife corridors and buffer zones for Lake Manyara National Park, Tanzania, and its immediate environment. Biological Conservation 57:171-186.

Myers, N., Mittermeier, R. A., Mittermeier, C. G., Da Fonseca, G. A., \& Kent, J. (2000). Biodiversity hotspots for conservation priorities. Nature, 403(6772), 853-858.

Nahonyo, C. L. (2005). Assessment of anti-poaching effort in Ruaha national park, Tanzania. Tanzania Journal of Science, 31(2), 13-21.

National Forest Resources Monitoring and Assessment of Tanzania Mainland (2015): Main results (Cited as NAFORMA, 2015).

Newmark, W. D. (2008). Isolation of African protected areas. Frontiers in Ecology and the Environment, 6(6), 321-328.

Olofsson, P., Foody, G. M., Herold, M., Stehman, S. V., Woodcock, C. E., \& Wulder, M. A. (2014). Good practices for estimating area and assessing accuracy of land change. Remote Sensing of Environment, 148, 42-57.

Parks, S. A., \& Harcourt, A. H. (2002). Reserve size, local human density, and mammalian extinctions in US protected areas. Conservation Biology, 16(3), 800-808.

Pelkey, N. W., Stoner, C. J., \& Caro, T. M. (2000). Vegetation in Tanzania: assessing long term trends and effects of protection using satellite imagery. Biological Conservation, 94(3), 297-309.

Pfeifer, M., Burgess, N. D., Swetnam, R. D., Platts, P. J., Willcock, S., \& Marchant, R. (2012). Protected areas: mixed success in conserving East Africa's evergreen forests. PloS one, 7(6), e39337.

Pimm, S. L., \& Raven, P. (2000). Biodiversity: extinction by numbers. Nature, 403(6772), 843-845.

Pimm, S. L., Russell, G. J., Gittleman, J. L., \& Brooks, T. M. (1995). The future of biodiversity. Science-AAAS-Weekly Paper Edition, 269(5222), 347-349.

R Core Team (2016). R: A language and environment for statistical computing R Foundation for Statistical Computing, Vienna, Austria. URL https://www.Rproject.org/.

Rao, M., Naro-Maciel, E., \& Sterling, E. J. (2009) Protected Areas and Biodiversity Conservation II: Management and Effectiveness. 
Rodrigues, A. S., Akcakaya, H. R., Andelman, S. J., Bakarr, M. I., Boitani, L., Brooks, T. M., ... \& Hoffmann, M. (2004a). Global gap analysis: priority regions for expanding the global protected-area network. BioScience, 54(12), 1092-1100.

Rodrigues, A. S., Andelman, S. J., Bakarr, M. I., Boitani, L., Brooks, T. M., Cowling, R. M., ... \& Long, J. S. (2004b). Effectiveness of the global protected area network in representing species diversity. Nature, 428(6983), 640-643.

Rutasitara, L., Lokina, R. B., \& Yona, F. (2010). Mainstreaming Environment into MKUKUTA II process.

Schulz, J. J., Cayuela, L., Echeverria, C., Salas, J., \& Rey Benayas, J. M. (2010). Monitoring land cover change of the dryland forest landscape of Central Chile (1975e2008). Applied Geography, 30(3), 436-447.

Serra, P., Pons, X., \& Sauri, D. (2008). Land-cover and land-use change in a Mediterranean landscape: a spatial analysis of driving forces integrating biophysical and human factors. Applied Geography, 28(3), 189-209.

Shalaby, A., \& Tateishi, R. (2007). Remote sensing and GIS for mapping and monitoring land cover and land-use changes in the Northwestern coastal zone of Egypt. Applied Geography, 27(1), 28-41.

Singh, A. (1989). Digital change detection techniques using remotely-sensed data. International Journal of Remote Sensing, 10(6), 989-1003.

Stoner, C., Caro, T. I. M., Mduma, S., Mlingwa, C., Sabuni, G., \& Borner, M. (2007a). Assessment of effectiveness of protection strategies in Tanzania based on a decade of survey data for large herbivores. Conservation Biology, 21(3), 635-646.

Stoner, C., Caro, T., Mduma, S., Mlingwa, C., Sabuni, G., Borner, M., \& Schelten, C. (2007b). Changes in large herbivore populations across large areas of Tanzania. African Journal of Ecology, 45(2), 202-215.

TAWIRI/Cimu (2014) Aerial Census in the Ruaha-Rungwa Ecosystem. Dry Season. Unpublished Report.

USAID (2013) Tanzania Wildlife Management Areas Evaluation. Final Evaluation Report. http://www.maliasili.org/wp-content/uploads/2014/01/USAIDWMA.pdf. Accessed on 19th November 2016 
Vandermeer, J., \& Perfecto, I. (2007). The agricultural matrix and a future paradigm for conservation. Conservation biology, 21(1), 274-277.

Wittemyer, G., Elsen, P., Bean, W. T., Burton, A. C. O., \& Brashares, J. S. (2008). Accelerated human population growth at protected area edges. Science, 321(5885), 123-126.

Wuyts, M., \& Kilama, B. (2015). Planning for Agricultural Change and Economic Transformation in Tanzania?. Journal of Agrarian Change.

WWF (2014). Tanzania's Wildlife Management Areas: A 2012 Status Report. WWF, Dar es Salaam.

http://www.twma.co.tz/uploads/WMA_Status_Report_2012_Final.pdf.

Accessed on 19th November 2016

WWF (2016). Living Planet Report 2016. Risk and resilience in a new era. WWF International, Gland, Switzerland

Wyman, M. S., \& Stein, T. V. (2010). Modelling social and land-use/land-cover change data to assess drivers of smallholder deforestation in Belize. Applied Geography, 30(3), 329-342.

Zuidema, P. A., \& Sayer, J. A. (2003). Tropical forests in multi-functional landscapes: the need for new approaches to conservation and research. Tropical forests in multi-functional landscapes. Prince Bernhard Centre for International Nature Conservation, Utrecht University, Utrecht, The Netherlands, 9-19. 


\section{Appendices}

Appendix A: List of satellite images used in the study

\begin{tabular}{|c|c|c|}
\hline Sensor type & Scene No. & $\begin{array}{l}\text { Date of } \\
\text { acquisition }\end{array}$ \\
\hline MSS & LM11800641974007AAA04 & $07 / 01 / 1974$ \\
\hline MSS & LM11800651974007AAA04 & $07 / 01 / 1974$ \\
\hline MSS & LM11800661972216AAA02 & 03/08/1972 \\
\hline MSS & LM11810641973247AAA02 & $09 / 09 / 1972$ \\
\hline MSS & LM11810651972253AAA05 & $09 / 09 / 1972$ \\
\hline MSS & LM11810661973265AAA05 & $09 / 09 / 1972$ \\
\hline MSS & LM11820641973176FAK03 & $09 / 10 / 1972$ \\
\hline MSS & LM11820651972272AAA05 & $09 / 10 / 1972$ \\
\hline MSS & LM11820661972254AAA05 & $09 / 10 / 1972$ \\
\hline MSS & LM11830641973231AAA05 & $19 / 08 / 1973$ \\
\hline MSS & LM11830651972255AAA05 & $11 / 09 / 1972$ \\
\hline MSS & LM11830661972255AAA05 & $11 / 09 / 1972$ \\
\hline TM & LE71680641999305EDC00 & $07 / 11 / 1990$ \\
\hline TM & LT51680651999041JSA00 & $07 / 11 / 1990$ \\
\hline TM & LT51680661998134JSA00 & $07 / 11 / 1990$ \\
\hline $\mathrm{TM}$ & LT51690641997218JSA00 & $06 / 16 / 1990$ \\
\hline TM & LT51690651997186JSA00 & $06 / 16 / 1990$ \\
\hline TM & LT51690661998285JSA00 & $06 / 16 / 1990$ \\
\hline TM & LT51700641997177JSA00 & $23 / 06 / 1990$ \\
\hline TM & LT51700651997177JSA00 & $23 / 06 / 1990$ \\
\hline TM & LT51700661997177JSA00 & $23 / 06 / 1990$ \\
\hline TM & LT51710641997184JSA00 & $16 / 07 / 1990$ \\
\hline $\mathrm{TM}$ & LT51710651997232JSA00 & $16 / 07 / 1990$ \\
\hline TM & LT51710661997232JSA00 & $16 / 07 / 1990$ \\
\hline ETM+ & LC81680642014034LGN00 & $09 / 18 / 2015$ \\
\hline ETM+ & LC81680652014034LGN00 & $09 / 18 / 2015$ \\
\hline ETM+ & LC81680662013303LGN00 & $09 / 21 / 2015$ \\
\hline ETM+ & LC81690642013230LGN00 & $09 / 09 / 2015$ \\
\hline ETM+ & LC81690652013230LGN00 & $09 / 09 / 2015$ \\
\hline ETM+ & LC81690662013294LGN00 & $09 / 09 / 2015$ \\
\hline ETM+ & LC81700642013253LGN00 & $08 / 31 / 2015$ \\
\hline ETM+ & LC81700652013253LGN00 & $08 / 31 / 2015$ \\
\hline
\end{tabular}


bioRxiv preprint doi: https://doi.org/10.1101/117622; this version posted March 17, 2017. The copyright holder for this preprint (which was not certified by peer review) is the author/funder. All rights reserved. No reuse allowed without permission.

\begin{tabular}{|l|l|l|}
\hline ETM+ & LC81700662013269LGN00 & $08 / 31 / 2015$ \\
\hline ETM+ & LC81710642013260LGN00 & $09 / 23 / 2015$ \\
\hline ETM+ & LC81710652013244LGN00 & $09 / 23 / 2015$ \\
\hline ETM+ & LC81710662013228LGN00 & $09 / 23 / 2015$ \\
\hline
\end{tabular}


Appendix B: Landsat MSS satellite index

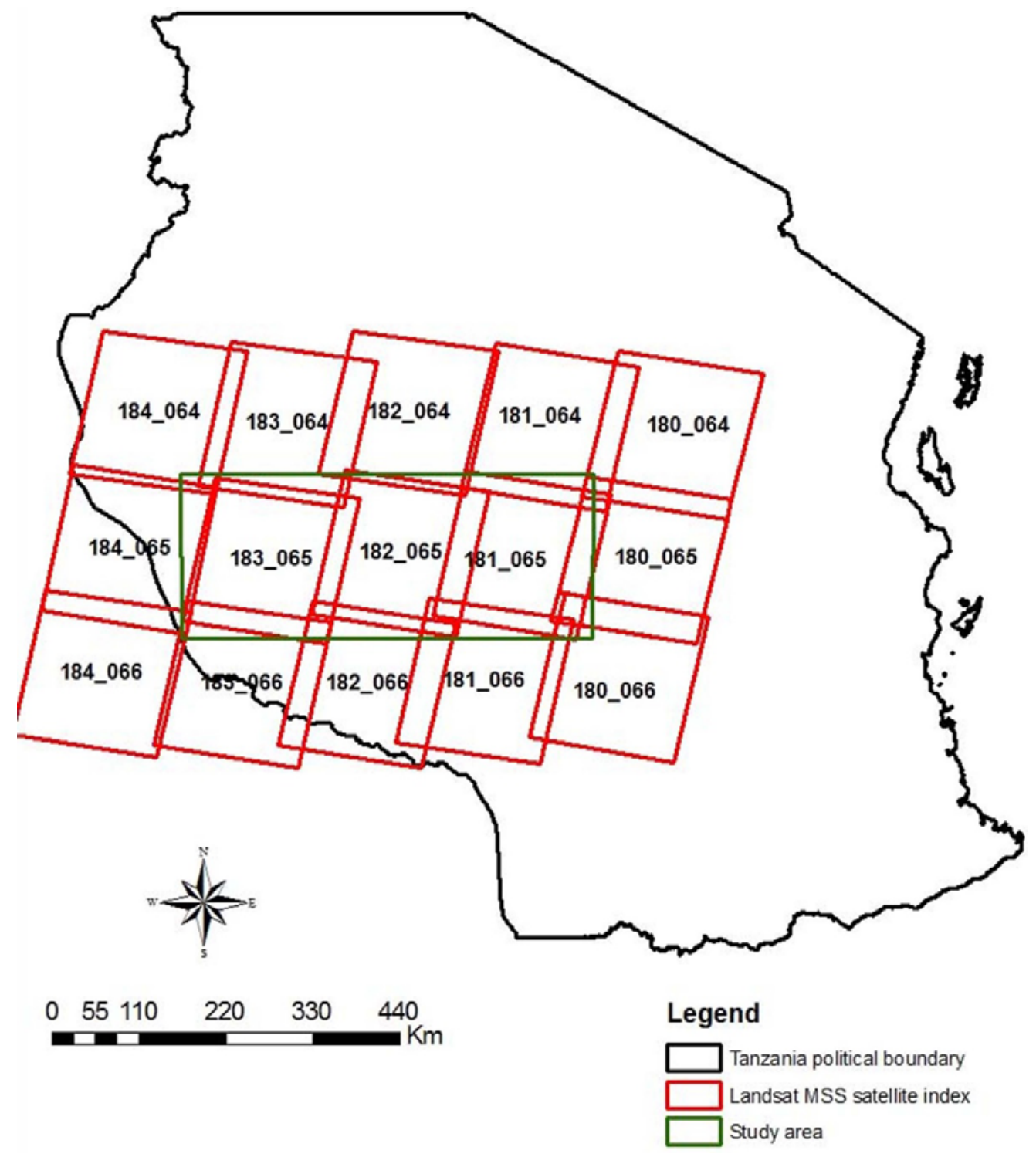


Appendix C: Landsat TM/ETM+ satellite index

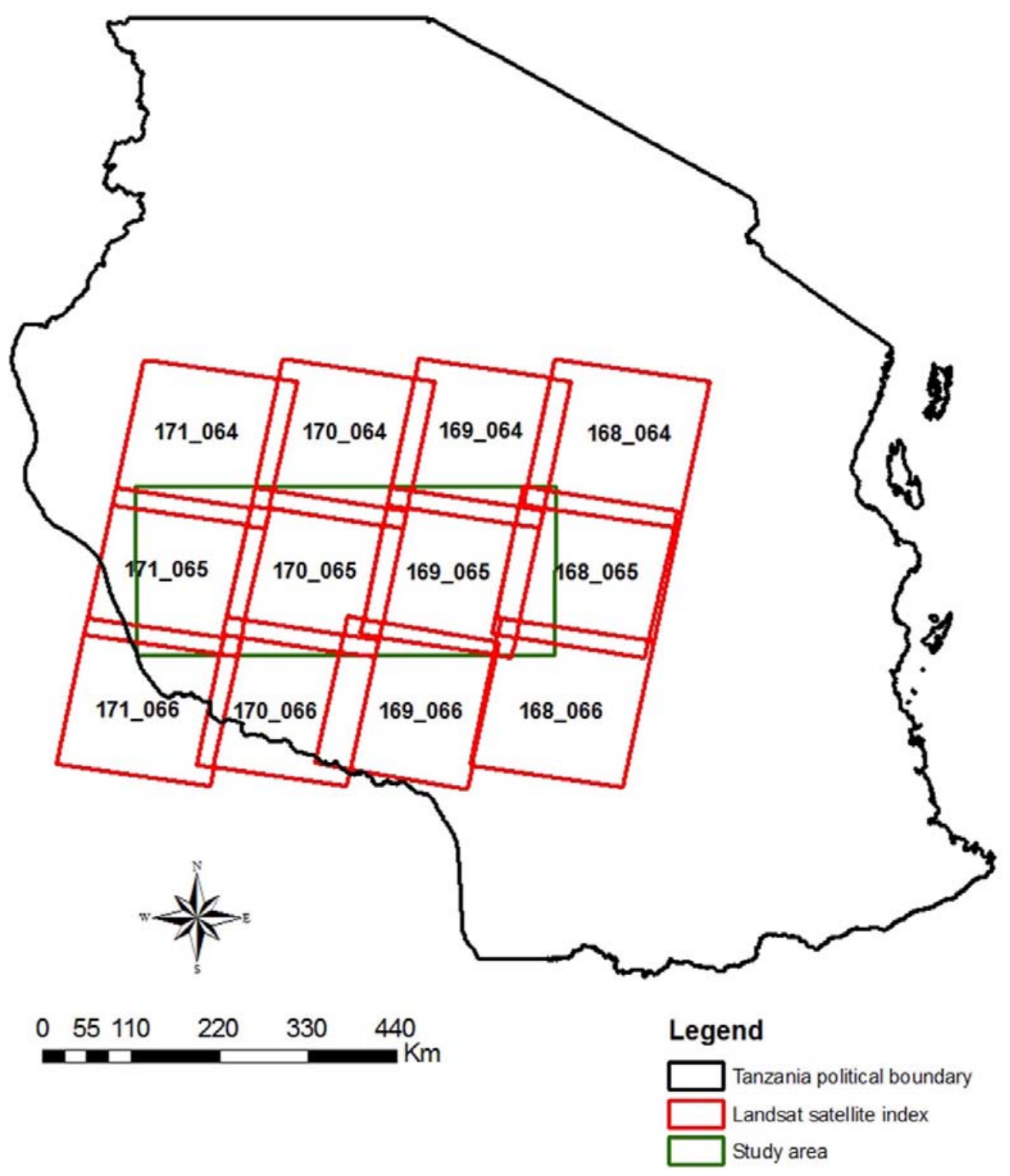


Appendix D: Habitat loss (in Sq.km) in the Region of Interest (ROI) between the two ecosystems

\begin{tabular}{|c|c|c|c|c|c|c|}
\hline Landuse & Habitat 1972 & Habitat 1990 & Habitat 2015 & $\begin{array}{c}\text { Change 1972- } \\
1990\end{array}$ & $\begin{array}{c}\text { Change 1990- } \\
2015\end{array}$ & $\begin{array}{c}\text { Change 1972- } \\
2015\end{array}$ \\
\hline Rungwa River GCA & 2494 & 2443 & 2418 & -51.5 & -24.2 & -75.8 \\
\hline Inyonga East GCA & 3638 & 3608 & 2929 & -30.0 & -678.9 & -709.0 \\
\hline Piti East OA & 2751 & 2732 & 1740 & -19.3 & -991.1 & -1010.4 \\
\hline Rungwa South OA & 1828 & 1813 & 1639 & -15.2 & -173.2 & -188.4 \\
\hline Chunya East OA & 1376 & 1367 & 1269 & -8.3 & -98.1 & -106.5 \\
\hline Ituru Forest OA & 1328 & 1326 & 1162 & -2.4 & -163.3 & -165.8 \\
\hline Rungwa Mzombe OA & 1945 & 1909 & 1873 & -36.6 & -35.2 & -71.8 \\
\hline Inyonga West GCA & 1645 & 1644 & 1620 & -1.0 & -24.3 & -25.3 \\
\hline Inyonga Central GCA & 2103 & 2106 & 1910 & 2.6 & -195.9 & -193.3 \\
\hline Mlele North GCA & 3429 & 3343 & 3057 & -86.3 & -285.9 & -372.2 \\
\hline Msima East GCA & 1009 & 1007 & 1007 & -2.1 & -0.2 & -2.3 \\
\hline Wembere South GCA & 1120 & 1108 & 822 & -11.9 & -286.0 & -297.9 \\
\hline Rungwa North $O A$ & 2158 & 2141 & 1106 & -17.0 & -1035.2 & -1052.1 \\
\hline Chunya Msami OA & 1676 & 1645 & 1577 & -30.4 & -68.4 & -98.8 \\
\hline Chunya Lukwati OA & 2318 & 2308 & 1961 & -9.4 & -347.1 & -356.4 \\
\hline
\end{tabular}

Overall loss

$(318.85)$

$(4,407.19)$

$(4,726.04)$

Overall \% loss

$1.0 \quad 14.3$

15.3 
Appendix E: Prevented habitat loss (in Sq.km) in fully protected areas in the study area

\begin{tabular}{|c|c|c|c|c|c|c|}
\hline Landuse & $\begin{array}{l}\text { Habitat } \\
1972\end{array}$ & $\begin{array}{l}\text { Habitat } \\
1990\end{array}$ & $\begin{array}{l}\text { Habitat } \\
2015\end{array}$ & $\begin{array}{l}\text { Change } \\
1972- \\
1990\end{array}$ & $\begin{array}{l}\text { Change } \\
1990- \\
2015\end{array}$ & $\begin{array}{l}\text { Change } \\
1972- \\
2015\end{array}$ \\
\hline Ruaha NP & $14,972.10$ & $14,972.14$ & $14,971.88$ & 0.00 & 0.00 & 0.00 \\
\hline Katavi NP & $4,238.81$ & $4,238.81$ & $4,238.81$ & 0.00 & 0.00 & 0.00 \\
\hline Lukwati GR & $3,572.98$ & $3,572.96$ & $3,572.97$ & 0.00 & 0.00 & 0.01 \\
\hline Rungwa GR & $8,878.05$ & $8,878.05$ & $8,878.01$ & 0.00 & 0.00 & 0.00 \\
\hline Muhesi GR & $1,145.15$ & $1,145.13$ & $1,058.74$ & 0.00 & 0.00 & 86.41 \\
\hline Lwafi GR & $2,259.84$ & $2,259.83$ & $2,235.13$ & 0.00 & 0.00 & 24.72 \\
\hline Kisigo GR & $5,014.72$ & $5,014.71$ & $5,013.43$ & 0.00 & 0.00 & 0.00 \\
\hline Rukwa GR & $4,192.60$ & $4,192.56$ & $4,157.98$ & 0.00 & 0.00 & 34.62 \\
\hline \multirow[t]{3}{*}{ Piti GR } & $1,687.00$ & $1,769.18$ & $2,072.81$ & 0.00 & 0.00 & 0.00 \\
\hline & $45,961.25$ & $46,043.37$ & $46,199.76$ & - & 0.01 & 145.77 \\
\hline & & & Change & - & - & 0.32 \\
\hline
\end{tabular}


Appendix F: Overall habitat loss (in Sk.km) in individual PA designations the entire study area

\begin{tabular}{|c|c|c|c|c|c|c|c|}
\hline Landuse & $\begin{array}{c}\text { Habitat } \\
1972 \\
\end{array}$ & $\begin{array}{c}\text { Habitat } \\
1990\end{array}$ & $\begin{array}{c}\text { Habitat } \\
2015\end{array}$ & $\begin{array}{c}\text { Change } \\
1972- \\
1990 \\
\end{array}$ & $\begin{array}{c}\text { Change } \\
1990- \\
2015 \\
\end{array}$ & $\begin{array}{c}\text { Change } \\
1972- \\
2015 \\
\end{array}$ & 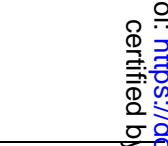 \\
\hline Rungwa River GCA & 2494 & 2443 & 2418 & -51.5 & -24.2 & & -75.8 \\
\hline Inyonga East GCA & 3638 & 3608 & 2929 & -30.0 & -678.9 & & $-709 . \mathbb{D}_{\infty}^{\circ} \frac{0}{c}$ \\
\hline Piti East OA & 2751 & 2732 & 1740 & -19.3 & -991.1 & & -1010.8 \\
\hline Rungwa South OA & 1828 & 1813 & 1639 & -15.2 & -173.2 & & $-188 \cdot \frac{\operatorname{sen}}{\omega}=$ \\
\hline Chunya East OA & 1376 & 1367 & 1269 & -8.3 & -98.1 & & $-106 . \bar{\Phi}$ \\
\hline Ituru Forest OA & 1328 & 1326 & 1162 & -2.4 & -163.3 & & $-165.8 \AA$ \\
\hline Rungwa Mzombe OA & 1945 & 1909 & 1873 & -36.6 & -35.2 & & -71. \\
\hline Inyonga West GCA & 1645 & 1644 & 1620 & -1.0 & -24.3 & & $-25 . \overline{\overrightarrow{3}} \frac{\overrightarrow{0}}{\omega}$ \\
\hline Inyonga Central GCA & 2103 & 2106 & 1910 & 2.6 & -195.9 & & $-193 . \frac{2}{3}$ \\
\hline Lunda Nkwabi GCA & 3380 & 2638 & 2121 & -741.8 & -516.5 & & -1258. \\
\hline Mlele North GCA & 3429 & 3343 & 3057 & -86.3 & -285.9 & & $-372 . \frac{2}{2} \stackrel{0}{\square}$ \\
\hline Msima East GCA & 1009 & 1007 & 1007 & -2.1 & -0.2 & & -2. \\
\hline Wembere South GCA & 1120 & 1108 & 822 & -11.9 & -286.0 & & $-297 . \frac{9}{9}$ \\
\hline Rungwa North OA & 2158 & 2141 & 1106 & -17.0 & -1035.2 & & -1052.4 \\
\hline Chunya Msami OA & 1676 & 1645 & 1577 & -30.4 & -68.4 & & -98.8 \\
\hline Chunya Lukwati OA & 2318 & 2308 & 1961 & -9.4 & -347.1 & & $-356.8 \overline{8} \overline{\bar{\sigma}}$ \\
\hline Ruaha NP & $14,972.10$ & $14,972.14$ & $14,971.88$ & 0.00 & 0.00 & & $0.0 \stackrel{0}{0}$ \\
\hline Katavi NP & $4,238.81$ & $4,238.81$ & $4,238.81$ & 0.00 & 0.00 & & $0.0 . \overline{8}$ \\
\hline Lukwati GR & $3,572.98$ & $3,572.96$ & $3,572.97$ & 0.00 & 0.00 & & 0.0 乲产 \\
\hline Rungwa GR & $8,878.05$ & $8,878.05$ & $8,878.01$ & 0.00 & 0.00 & & $0.0 \overline{\mathrm{\theta}}$ \\
\hline Muhesi GR & $1,145.15$ & $1,145.13$ & $1,058.74$ & 0.00 & 0.00 & & $86.4 \frac{\sqrt[c]{7}}{2}$ \\
\hline Lwafi GR & $2,259.84$ & $2,259.83$ & $2,235.13$ & 0.00 & 0.00 & & 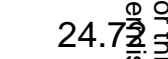 \\
\hline Kisigo GR & $5,014.72$ & $5,014.71$ & $5,013.43$ & 0.00 & 0.00 & & 0.0 要需 \\
\hline Rukwa GR & $4,192.60$ & $4,192.56$ & $4,157.98$ & 0.00 & 0.00 & & $34.62 \frac{\pi}{0}$ \\
\hline Piti GR & $1,687.00$ & $1,769.18$ & $2,072.81$ & 0.00 & 0.00 & & $0.00 \stackrel{\equiv}{3}$ \\
\hline
\end{tabular}




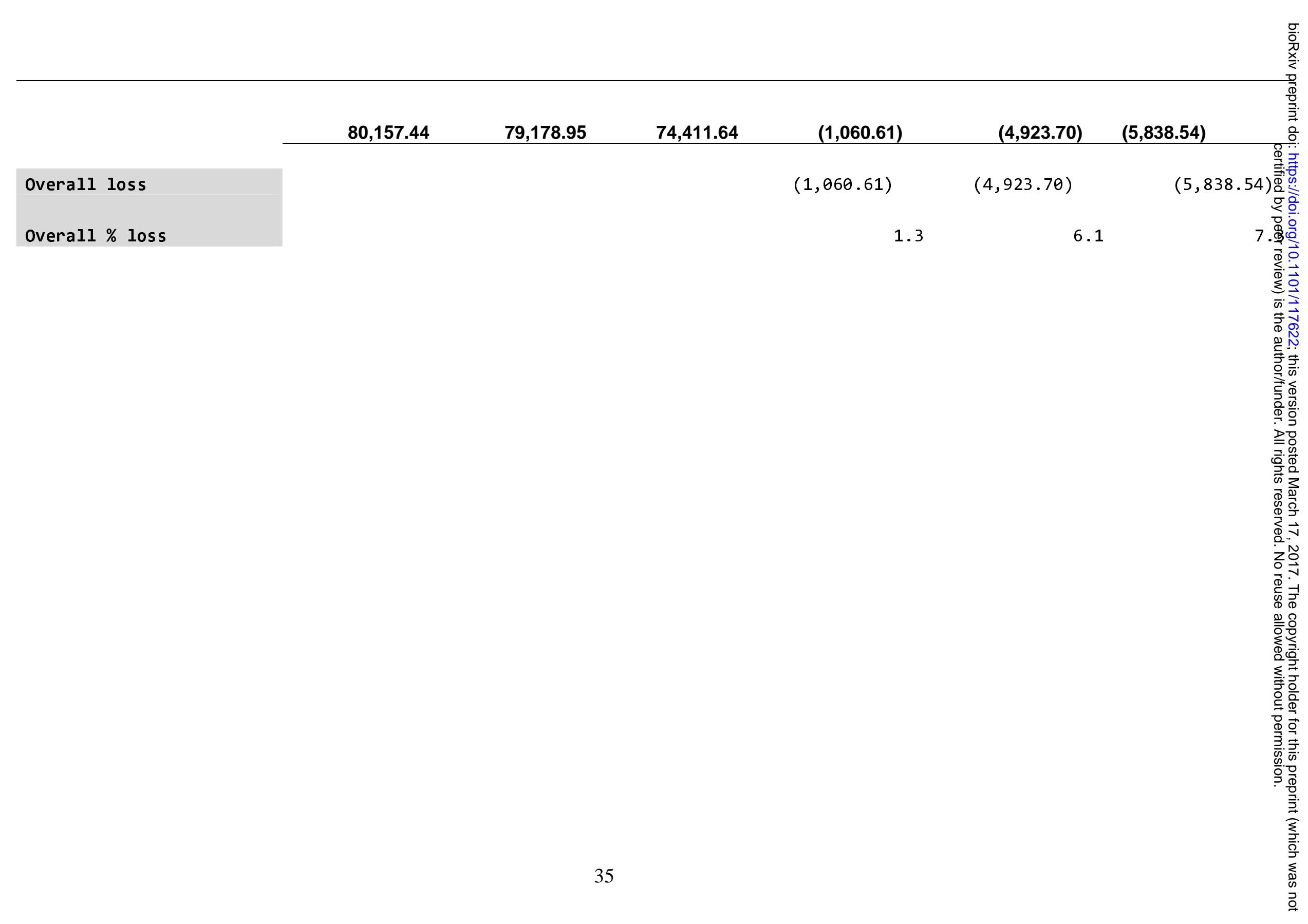


Appendix G: Selective logging of valuable tree species in Rungwa Game Reserve in the study area

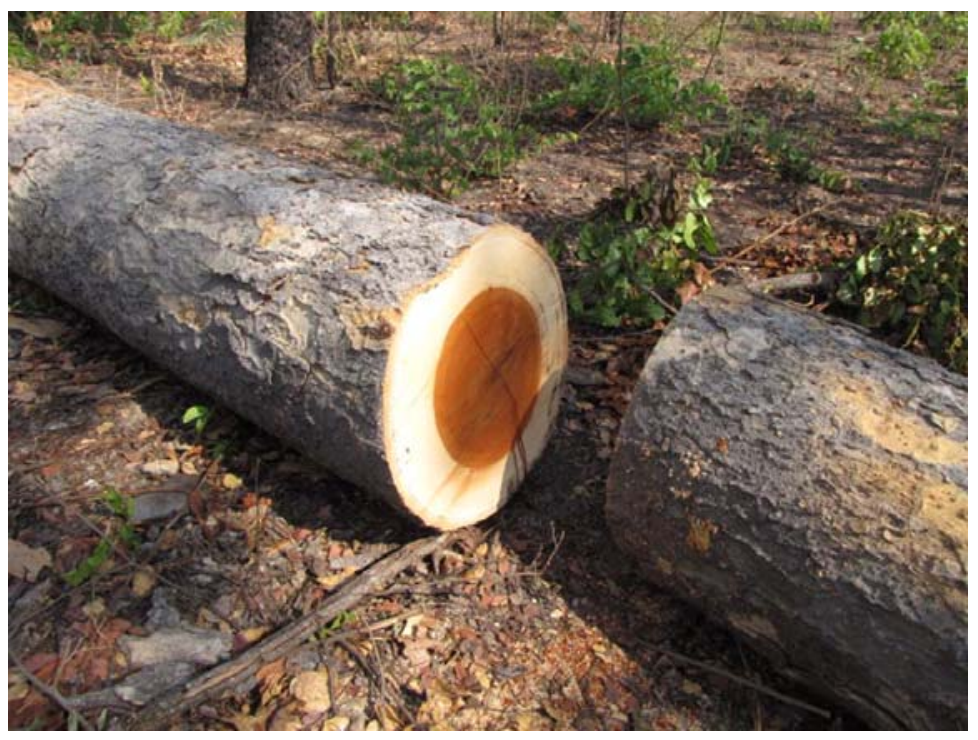

G (1) Abandoned Afzelia quanzensis log in Rungwa Game Reserve in the study area. Other names include pod mahogany (spectacle case) and East African Afzelia. Encroachment happens during wet season when most areas within the reserve are inaccessible by vehicles which is often used by game scouts during patrols. It is valued for joinery and makes attractive doors, window frames and flooring among others.

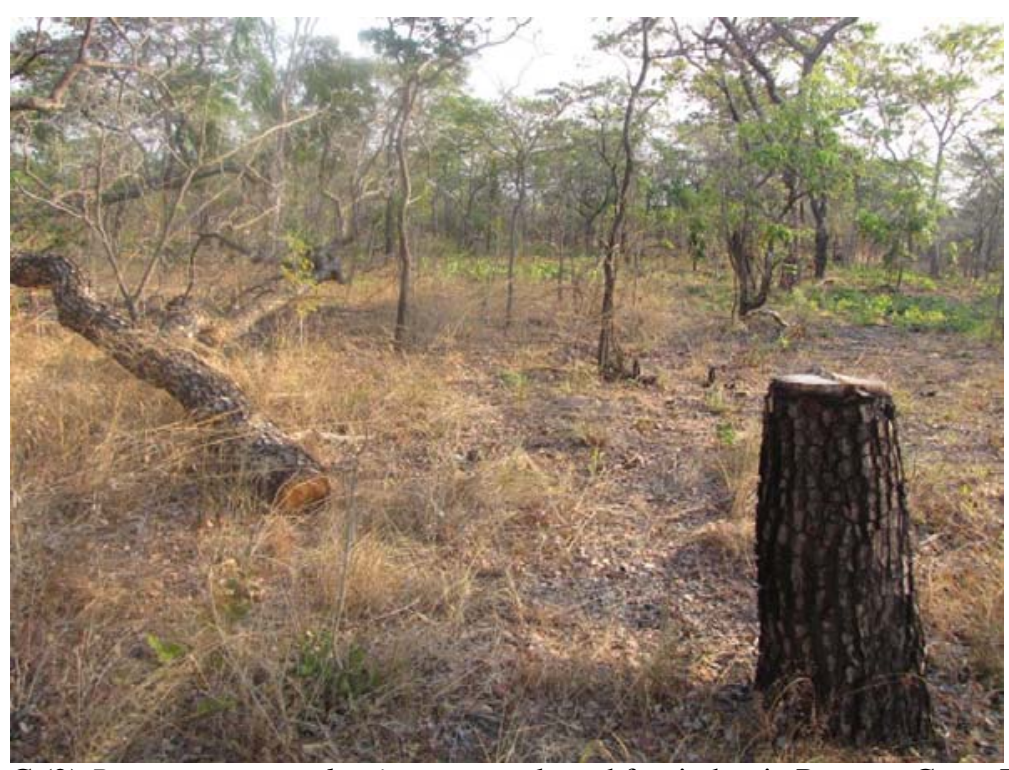

G (2) Pterocarpus angolensis remnant cleared for timber in Rungwa Game Reserve in the study area. It is regarded as a high valuable tree providing the highest timber quality in the market. Other names include bloodwood, paddle-wood, sealing-wax tree and wild teak. 
Appendix H: R script used to calculate change detection

\# Set working directory:

Setwd

\#Load libraries:

library(raster)

library(INLA)

library(spdep)

library(rgdal)

\section{\# Reads in the raster files:}

lc_1972 <- raster("landcover1972.tif" ,overwrite=TRUE)

lc_1990 <- raster("landcover1990.tif",overwrite=TRUE)

lc_2015 <-raster("landcover2015.tif",overwrite=TRUE)

land_use <-raster("SA_lu_utm_36s.tif",overwrite=TRUE)

\section{\#Crop layers to ensure they all have the same extent}

lc_1972<-crop(lc_1972, extent(lc_1990), filename = "lc_1972_crop.tif", overwrite $=$ TRUE)

lc_1990 <- crop(lc_1990, extent(lc_1990), filename = "lc_1990_crop.tif", overwrite=TRUE)

lc_2015 <- crop(lc_2015, extent(1c_1990), filename = "lc_2015_crop.tif", overwrite $=$ TRUE)

\section{\# Reprojects the rasters to the same extent and origin as roads}

lc_2015 <- projectRaster(lc_2015, roads, method = "ngb", filename ="lc2015_final.tif")

lc_1990 <- projectRaster(lc_1990, roads, method = "ngb", filename = "lc1990_final.tif")

lc_1972 <- projectRaster(lc_1972, roads, method = "ngb", filename = "lc1972_final.tif")

land_use <- projectRaster(land_use, roads, method = "ngb", filename =

"landuse_final.tif")

\# creates the change rasters based on classes that originally were not 24 (crops) but are by the second period

1c_change_72_90 <- writeRaster(lc_1972 != $24 \&$ lc_1990 == 24, file =

"Change_72_90.tif") 
lc_change_90_15 <- writeRaster(lc_1990!= 24 \& 1c_2015 == 24, file =

"Change_90_15.tif")

lc_change_72_15 <- writeRaster(lc_1972 != 24 \& lc_2015 == 24, file =

"Change_72_15.tif")

\section{\# Calculate a change table:}

change_table_72_90 <- $\operatorname{matrix}(0, \operatorname{nrow}=7, \mathrm{ncol}=7$, dimnames $=\operatorname{list}(21: 27,21: 27))$

change_table_90_15 - $\operatorname{matrix}(0, \operatorname{nrow}=7, \mathrm{ncol}=7$, dimnames $=\operatorname{list}(21: 27,21: 27))$

change_table_72_15 <- matrix $(0, \operatorname{nrow}=7, \mathrm{ncol}=7$, dimnames $=\operatorname{list}(21: 27,21: 27))$

for (i in 21:27) \{ for ( $\mathrm{j}$ in 21:27)

\{change_table_72_90[as.character(i),

as.character(j)] <- sum(values (overlay(lc_1972,lc_1990,

fun=function $(\mathrm{x}, \mathrm{y}, \ldots)\{\operatorname{return}(\mathrm{x}==\mathrm{i} \& \mathrm{y}==\mathrm{j})\}))$, na.rm $=\mathrm{T})$

change_table_90_15[as.character(i), as.character(j)] <-sum(values

(overlay(lc_1990, lc_2015, fun=function $(\mathrm{x}, \mathrm{y}, \ldots)\{\operatorname{return}(\mathrm{x}==\mathrm{i} \& \mathrm{y}==$

j) $))$ ), na.rm = T) change_table_72_15[as.character(i),

as.character(j)] <-

sum(values(overlay(lc_1972, lc_2015, fun=function(x,y, ...)

$\{$ return

$$
(x==i \& y==j)\})), \text { na.rm }=T)\}\}
$$

